\title{
The Relationship between Leisure Satisfaction and Social Media Addictions of Individuals at University
}

\author{
Yesim Avunduk (Corresponding author) \\ Faculty of Economic, Administrative and Social Sciences \\ Istanbul Ayvansaray University, Ayvansaray Cd. No:45 D:45, 34662 Fatih, Istanbul, Turkey \\ Tel: 90-212-444-7696Ｅ-mail: dryavunduk@gmail.com
}

Received: May 5, 2021 Accepted: June 1, $2021 \quad$ Published: June 11, 2021

doi:10.5296/jei.v7i1.18592ＵRL: https://doi.org/10.5296/jei.v7i1.18592

\begin{abstract}
This study aimed to determine the relationship between leisure satisfaction and social media addiction of university students. The study group of the research was formed by the voluntary participation of 193 students (133 male and 60 female), studying at the School of Physical Education and Sports of Istanbul Gelişim University. In addition to the personal information form, the "Leisure Satisfaction Scale (LSS)" developed by Beard and Raghep (1980) and adapted into Turkish by Gökçe and Orhan (2011), and the "Social Media Addiction Scale (SMAS)" developed by Bakır Ayğar and Uzun (2018) were used as data collection tools. After the data showed normal distribution in the Kolmogrov-Smirnov normality test, T-test, ANOVA and Pearson Correlation test were used in the analysis. The level of significance in the study was set at 0.05 . In the research findings; gender and age groups of individuals affect their leisure time satisfaction levels; It has also been found that age groups affect social media addiction. As a result, it was determined that leisure satisfaction levels and social media addiction changed according to various variables of university students, and a negative significant relationship was found between leisure satisfaction and social media addiction.
\end{abstract}

Keywords: Leisure, Leisure satisfaction, Social media, Social media addiction

\section{Introduction}

Due to the development of technology, the advancement of science and the convenience brought to the working lives of people in the century we live in, the leisure of individuals is increasing today compared to the past (Jensen \& Naylor, 2005). The increasing importance of leisure in contemporary societies has caused scientists to focus on the meaning and importance of this time period (Hou, 2003). For instance, Edginton (2006) has stated that leisure is an important factor affecting the peace and welfare of people, societies and even 
nations in all respects, and Chen et al. (2013) have stated that these time frames are an important way for people to have feelings of pleasure, desire and success.

In a general definition, leisure activities are defined as a set of activities in which individuals participate in their leisure (Paggi et al., 2016). While Gürbüz and Henderson (2013) have stated that individuals benefit from both psychological and social aspects in their leisure time activities, Yang (2006) has shown that activities in leisure are used by people, he also has stated that it has benefits in many areas including social, mental, physical and social. In this context, individuals participating in these activities can socialize, develop their knowledge and skills, and achieve positive emotions ( $\mathrm{Li}$ et al., 2019).

Today, the satisfactions of individuals have gained when they participate in leisure activities is an important issue as a factor that affects each point of their lives (Gökçe, 2008), and it is one of the basic principles for increasing the quality of life of individuals (Çelik, 2011). Individuals should provide themselves with more opportunities in their daily lives for the satisfaction they obtain in leisure activities because these activities are extremely important for the happiness of individuals (Broughton \& Beggs, 2006), and the activities help individuals to increase their quality of life and to continue their daily life in a healthy way by moving them away from daily problems (Demiral, 2018).

With the participation of individuals in leisure activities, they obtain satisfaction from various aspects. This obtained satisfaction is expressed as leisure satisfaction (Broughton \& Beggs, 2006). Leisure satisfaction scale was developed by Beard and Raghep (1980) and has six sub-dimensions (psychological, educational, social, relaxation, physical, aesthetically) (Huang, 2003). When leisure time satisfaction is examined psychologically, it indicates the satisfaction gained in terms of the level of freedom that people perceive in leisure time activities (Beard \& Ragheb, 1980). Leisure satisfaction is explained as the individual's getting to know his/her environment, intellectual development and the satisfaction of learning and experiencing new things by educational sub-dimension (Ekinci, 2019). Social satisfaction achieved by individuals in leisure activities in which they participate helps them to establish a positive relationship with their environment (Huang, 2003). While the relaxation sub-dimension includes the release of the individual's stress and emotional peace (Choi \& Fu, 2015), the physiological sub-dimension consists of feelings of satisfaction from physiological benefits such as staying fit and healthy (Sönmezoğlu et al., 2014). The aesthetic sub-dimension, which individuals acquire in the leisure time activities they participate in, expresses the level of satisfaction obtained from the space and focus on the design of the space where the individual participates (Choi \& Fu, 2015).

Social media are online environments that enable people to introduce themselves in a social environment, and share their ideas, thoughts, photos, and videos with other people (Çolak, 2020). Turban et al. (2002) have defined social media as platforms where individuals share their photos, videos, music, thoughts and experiences. Especially in recent years, due to the the spread of the internet, the advancement of technology, and the fact that smart mobile phones, computers and tablets are indispensable devices of daily life for people, and the use of social media platforms have started to increase day by day (Bayraktar, 2020). The negative 
effects of these uncontrolled and excessive use of social media platforms on people are defined as social media addiction in the literature (Bilginer, 2020). Social media addiction symptoms are similar to addiction to other behaviours (Echeburua \& Corral, 2010). Wilson et al. (2010) have stated that visiting social media sites at least four times a day creates addiction.

The reason for their commitment to social media is the ability of people not only to communicate with family members or friends but also to many people from various parts of the world with each other through social platforms (Kuss \& Griffiths, 2011). Another reason for dependence on social media platforms is that people's desire to be aware of the events happening instantly, to make sense of the developments and to communicate with groups can be realized through social media platforms (Becan, 2018; Alkaya, 2020). Balta (2019) have concluded that the boredom, loneliness, unhappiness of individuals, insufficient communication with family members, communication established through social media and desire to be liked on social media are the causes of social media addiction.

In today's communication age, the intense use of social media (Alkaya, 2020) has started to reveal the negativities such as isolation from society, solitude, increasing dependence, decreasing sense of privacy, and disclosure of private life (Özçağlayan, 1998; Yayman, 2019). Moreover, the loss of privacy in private life causes family problems and humiliation of individuals in the eyes of society (Ulusoy, 2017). Longstreet and Brooks (2017) have stated that life satisfaction is an important factor in reducing social media addiction. Similarly, Siyahtaş (2020) have stated that the realization of life satisfaction and leisure satisfaction is inevitable for individuals to live a peaceful, happy, depressed and stress-free life. Therefore, it is necessary to examine leisure time satisfaction, which has an important effect on social media addiction among young people day by day. When the literature was examined, there were various studies on leisure satisfaction (Ito, 2017; Güngörmüş et al., 2018; Serdar, 2016; Muzindutsi \& Masango, 2015; Park et al., 2016; Akgül et al., 2015; Park et al., 2017; Serdar \& Mungan Ay, 2016; Matsumoto et al., 2018; Tercan Kaas \& Artımaç, 2017; Serdar et al., 2018; Yaşartürk, 2019). However, there are no studies examining the effect of leisure satisfaction on social media addiction. Therefore, the purpose of this study is to examine the relationship between the leisure satisfaction gained in leisure activities of university students and social media addiction.

\section{Method}

\subsection{Research Model}

Screening model, which is one of the quantitative research methods; It is a research model that seeks to identify existing or past situations. Among the scanning models, the relational scanning pattern is tried to determine the existence of change among variables, and if there is a change, how it is (Karasar, 2020). In this study, one of the quantitative research methods was conducted according to the scanning model and in accordance with the relational scanning pattern. 


\subsection{Research Group}

The study group consisted of 193 voluntarily participated students, 133 "males" (68.9\%) and 60 "females" (31.1\%), studying at the School of Physical Education and Sports in Gelişim University. Gelişim University is a private university located in the province of Istanbul.

\subsection{Data Collection Tools}

In this study, "leisure time satisfaction scale" and "social media addiction scale" were used in addition to personal information form.

\subsubsection{Personal Information Form}

The personal information form was created with the aim of determining the various personal characteristics (gender, age, department, class, wealth levels) of individuals.

\subsubsection{Leisure Satisfaction Scale (LSS)}

LSS was developed by Beard and Raghep (1980) and adapted into Turkish by Gökçe and Orhan (2011). LSS consisted of 24 items, 6 sub-dimensions (psychological, educational, social, relaxation, physical, aesthetic). The scale was 5-point Likert type ("rarely true", "rarely correct", "sometimes correct", "often true" an "almost always r-true"). To determine the internal consistency reliability of the Turkish version of LSS, the calculated Cronbach Alpha value for the overall scale was determined as .90 (Gökçe \& Orhan, 2011).

\subsubsection{Social Media Addiction Scale (SMAS)}

SMAS, developed by Bakır Ayğar and Uzun (2018), consisted of 26 items, and 3 sub-dimensions (functional deterioration, control difficulty and deprivation, social isolation). The scale was 5-point Likert type (1-never, 2-rarely, 3-occasionally, 4-often 5-always). While the minimum score that can be obtained from the scale was 26 , the maximum score was 130 . There were no reverse-coded items on the scale. The Cronbach alpha of internal consistency was calculated as .95 for the scale, .92 for the sub-dimension of control difficulty and deprivation, .91 for the sub-dimension of functional deterioration, and .81 for the sub-dimension of social isolation. The validity study of the scale was obtained by exploratory factor analysis.

\subsection{Data Analysis}

SPSS 20.0 package program was used in the statistical analysis of the data of the participants. The distribution of the demographic characteristics of the participants was made by the method of percentage (\%) and frequency (f). After understanding the normal distribution of the data in the Kolmogorov Smirnov normality test, T-test, ANOVA and Pearson correlation test were applied in the analyzes. Differences between groups were determined via the Tukey test. The level of significance was determined as 0.05 in the analyses. 


\section{Results}

Table 1. Demographic characteristics of individuals

\begin{tabular}{|c|c|c|c|}
\hline & & f & $\%$ \\
\hline \multirow{3}{*}{ Gender } & Male & 133 & 68.9 \\
\hline & Female & 60 & 31.1 \\
\hline & Total & 193 & 100.0 \\
\hline \multirow{5}{*}{ Class Level } & 1.Grade & 62 & 32.1 \\
\hline & 2. Grade & 40 & 20.7 \\
\hline & 3. Grade & 48 & 24.9 \\
\hline & 4. Grade & 43 & 22.3 \\
\hline & Total & 193 & 100.0 \\
\hline \multirow{4}{*}{ Department } & Sports management & 87 & 45.1 \\
\hline & Coaching Training & 65 & 33.7 \\
\hline & Recreation & 41 & 21.2 \\
\hline & Total & 193 & 100.0 \\
\hline \multirow{4}{*}{ Age } & $18-21$ & 68 & 35.2 \\
\hline & $22-25$ & 102 & 52.8 \\
\hline & 26 and older & 23 & 11.9 \\
\hline & Total & 193 & 100.0 \\
\hline \multirow{4}{*}{ Welfare Status } & High & 36 & 35.8 \\
\hline & Normal & 88 & 45.6 \\
\hline & Low & 69 & 18.7 \\
\hline & Total & 193 & 100.0 \\
\hline
\end{tabular}

In Table 1, the percentage and frequency information of the demographic information of the participants were given. According to Table 1, it was determined that $68.9 \%$ of the participants were male and $31.1 \%$ were female participants. It was determined that $32.1 \%$ of the participants were in the 1 st grade, $20.7 \%$ were in the 2 nd grade, $24.9 \%$ were in the $3 \mathrm{rd}$ grade, and $22.3 \%$ were in the 4 th grade. It was understood that $45.1 \%$ of the participants studied in the "sports management" department, $33.7 \%$ were in the "coaching education" and $21.2 \%$ were in the "recreation" department. It was determined that $35.2 \%$ of the participants 
were in the "18-21 age group", 52.8\% were in the "22-25 age group" and $11.9 \%$ were "26 years and older". Besides, it was determined that $35.8 \%$ of the participants stated their welfare status as "High", $45.6 \%$ as "Normal" and $18.7 \%$ as "Low".

Table 2. T-test results between LSS and SMAS according to the gender of the individuals

\begin{tabular}{|c|c|c|c|c|c|c|c|}
\hline & & $\mathbf{N}$ & Mean & Sd. & Sd. & $\mathbf{t}$ & $\mathbf{p}$ \\
\hline \multirow{2}{*}{ Leisure Satisfaction Scale (LSS) } & Male & 133 & 4.04 & 0.58 & \multirow{2}{*}{191} & \multirow{2}{*}{-.390} & \multirow{2}{*}{.697} \\
\hline & Female & 60 & 4.08 & 0.59 & & & \\
\hline \multirow{2}{*}{ Psychological } & Male & 133 & 4.07 & 0.60 & \multirow{2}{*}{191} & \multirow{2}{*}{.999} & \multirow{2}{*}{.319} \\
\hline & Female & 60 & 3.97 & 0.70 & & & \\
\hline \multirow{2}{*}{ Educational } & Male & 133 & 4.06 & 0.68 & \multirow{2}{*}{191} & \multirow{2}{*}{-.402} & \multirow{2}{*}{,688 } \\
\hline & Female & 60 & 4.11 & 0.70 & & & \\
\hline \multirow{2}{*}{ Social } & Male & 133 & 3.96 & 0.64 & \multirow{2}{*}{191} & \multirow{2}{*}{-2.771} & \multirow{2}{*}{$.035^{*}$} \\
\hline & Female & 60 & 4.14 & 0.63 & & & \\
\hline \multirow{2}{*}{ Relaxation } & Male & 133 & 4.07 & 0.78 & \multirow{2}{*}{191} & \multirow{2}{*}{-.860} & \multirow{2}{*}{.391} \\
\hline & Female & 60 & 4.18 & 0.84 & & & \\
\hline \multirow{2}{*}{ Physiological } & Male & 133 & 4.04 & 0.59 & \multirow{2}{*}{191} & \multirow{2}{*}{.582} & \multirow{2}{*}{.561} \\
\hline & Female & 60 & 3.98 & 0.65 & & & \\
\hline \multirow{2}{*}{ Aesthetic } & Male & 133 & 4.06 & 0.68 & \multirow{2}{*}{191} & \multirow{2}{*}{-3.578} & \multirow{2}{*}{$.000^{*}$} \\
\hline & Female & 60 & 4.11 & 0.70 & & & \\
\hline \multirow{2}{*}{ Social Media Addiction Scale (SMAS) } & Male & 133 & 3.69 & 0.55 & \multirow{2}{*}{191} & \multirow{2}{*}{-.338} & \multirow{2}{*}{.736} \\
\hline & Female & 60 & 3.72 & 0.42 & & & \\
\hline \multirow{2}{*}{ Functional deterioration } & Male & 133 & 4.03 & 0.56 & \multirow[b]{2}{*}{191} & & \\
\hline & Female & 60 & 4.07 & 0.58 & & -.449 & .654 \\
\hline & Male & 133 & 4.05 & 0.63 & & & \\
\hline Control difficuity and deprivation & Female & 60 & 4.08 & 0.64 & 191 & -.262 & .193 \\
\hline & Male & 133 & 4.23 & 0.95 & & & \\
\hline Social is oration & Female & 60 & 4.24 & 0.89 & 191 & -.031 & $.9 / 1$ \\
\hline
\end{tabular}

In Table 2, the T-test results between the LSS sub-dimensions and the SMAS sub-dimensions according to the gender of the participants. As a result, there was no statistically significant 
difference between the leisure satisfaction $\left(\mathrm{t}_{(191)}=-.390, \mathrm{p}>0.05\right)$ of individuals according to their gender, "psychological" $\left(\mathrm{t}_{(191)}=.999, \mathrm{p}>0.05\right)$, "educational" $\left(\mathrm{t}_{(191)}=-.402, \mathrm{p}>0.05\right)$, "relaxation" $\left(\mathrm{t}_{(191)}=-.860, \mathrm{p}>0.05\right)$, "physiological" $\left(\mathrm{t}_{(191)}=.582, \mathrm{p}>0.05\right)$ sub-dimensions of LSS, but a statistically significant difference was found between the "social" $\left(\mathrm{t}_{(191)}=\right.$ $-2.771, \mathrm{p}<0.05)$ and "aesthetic" $\left(\mathrm{t}_{(191)}=-3.578, \mathrm{p}<0.05\right)$ sub-dimensions.

According to the analysis results, there was no statistically significant difference between Social Media Addiction ( $\left.\mathrm{t}_{(191)}=-.338, \mathrm{p}>0.05\right)$, “Functional deterioration" $\left(\mathrm{t}_{(191)}=-.449\right.$, $\mathrm{p}>0.05)$, "control difficulties and deprivation" $\left(\mathrm{t}_{(191)}=-.262, \mathrm{p}>0.05\right)$, and "social isolation" $\left(\mathrm{t}_{(191)}=-.037, \mathrm{p}>0.05\right)$ sub-dimensions of SMAS regarding gender variable.

Table 3. ANOVA results between LSS and SMAS according to the ages of the participants

\begin{tabular}{|c|c|c|c|c|c|c|c|}
\hline & & $\mathbf{N}$ & Mean & Sd. & $\mathbf{F}$ & $\mathbf{p}$ & Difference \\
\hline \multirow{3}{*}{ Leisure Satisfaction Scale } & $18-21$ & 68 & 4.24 & .45 & \multirow{3}{*}{6.404} & \multirow{3}{*}{$.002^{*}$} & \multirow{3}{*}{$1-2$} \\
\hline & $22-25$ & 102 & 3.91 & .64 & & & \\
\hline & 26 and older & 23 & 4.05 & .55 & & & \\
\hline \multirow{3}{*}{ Psychological } & $18-21$ & 68 & 4.21 & .60 & \multirow{3}{*}{4.364} & \multirow{3}{*}{$.014^{*}$} & \multirow{3}{*}{$1-2$} \\
\hline & $22-25$ & 102 & 3.91 & .64 & & & \\
\hline & 26 and older & 23 & 4.01 & .61 & & & \\
\hline \multirow{3}{*}{ Educational } & $18-21$ & 68 & 4.29 & .56 & \multirow{3}{*}{6.313} & \multirow{3}{*}{$.002^{*}$} & \multirow{3}{*}{$1-2$} \\
\hline & $22-25$ & 102 & 3.90 & .74 & & & \\
\hline & 26 and older & 23 & 4.13 & .64 & & & \\
\hline \multirow{3}{*}{ Social } & $18-21$ & 68 & 4.20 & .49 & \multirow{3}{*}{2.773} & \multirow{3}{*}{.086} & \\
\hline & $22-25$ & 102 & 3.90 & .70 & & & \\
\hline & 26 and older & 23 & 3.91 & .67 & & & \\
\hline \multirow{3}{*}{ Relaxation } & $18-21$ & 68 & 4.30 & .67 & \multirow{3}{*}{5.250} & \multirow{3}{*}{$.006^{*}$} & \multirow{3}{*}{$1-2$} \\
\hline & $22-25$ & 102 & 3.91 & .88 & & & \\
\hline & 26 and older & 23 & 4.26 & .68 & & & \\
\hline \multirow{3}{*}{ Physiological } & $18-21$ & 68 & 4.16 & .60 & \multirow{3}{*}{1.577} & \multirow{3}{*}{.122} & \\
\hline & $22-25$ & 102 & 3.94 & .60 & & & \\
\hline & 26 and older & 23 & 3.97 & .64 & & & \\
\hline \multirow{3}{*}{ Aesthetic } & $18-21$ & 68 & 4.29 & .56 & \multirow{3}{*}{6.554} & \multirow{3}{*}{$.000^{*}$} & \multirow{3}{*}{$1-2$} \\
\hline & $22-25$ & 102 & 3.90 & .74 & & & \\
\hline & 26 and older & 23 & 4.13 & .64 & & & \\
\hline
\end{tabular}




\begin{tabular}{|c|c|c|c|c|c|c|c|}
\hline \multirow{3}{*}{ Social Media Addiction Scale } & $18-21$ & 68 & 3.57 & .62 & \multirow{3}{*}{4.386} & \multirow{3}{*}{.014} & \multirow{3}{*}{$1-2$} \\
\hline & $22-25$ & 102 & 3.80 & .40 & & & \\
\hline & 26 and older & 23 & 3.67 & .56 & & & \\
\hline \multirow{3}{*}{ Functional deterioration } & $18-21$ & 68 & 4.23 & .44 & \multirow{3}{*}{6.767} & \multirow{3}{*}{.001} & \multirow{3}{*}{$1-2$} \\
\hline & $22-25$ & 102 & 3.92 & .62 & & & \\
\hline & 26 and older & 23 & 4.02 & .54 & & & \\
\hline \multirow{3}{*}{ Control difficulty and deprivation } & $18-21$ & 68 & 4.23 & .53 & \multirow{3}{*}{4.768} & \multirow{3}{*}{.010} & \multirow{3}{*}{$1-2$} \\
\hline & $22-25$ & 102 & 3.92 & .68 & & & \\
\hline & 26 and older & 23 & 4.06 & .59 & & & \\
\hline \multirow{3}{*}{ Social isolation } & $18-21$ & 68 & 4.05 & 1.11 & \multirow{3}{*}{1.432} & \multirow{3}{*}{.241} & \\
\hline & $22-25$ & 102 & 4.43 & .77 & & & \\
\hline & 26 and older & 23 & 4.17 & .85 & & & \\
\hline
\end{tabular}

In Table 3, ANOVA test results were given to determine the significant differences between LSS sub-dimensions and SMAS sub-dimensions according to the age groups of participants. According to the analysis results, while it was determined that there was a significant difference between leisure satisfaction $\left(\mathrm{F}_{(2-191)}=6.404 \mathrm{p}<0.05\right)$, "psychological" $\left(\mathrm{F}_{(2-191)}=\right.$ 4.364, $\mathrm{p}<0.05)$, "educational" $\left(\mathrm{F}_{(2-191)}=6.313, \mathrm{p}<0.05\right)$, "relaxation" $\left(\mathrm{F}_{(2-191)}=5.250, \mathrm{p}<\right.$ $0.05)$, and "aesthetics" $\left(\mathrm{F}_{(2-191)}=6.554, \mathrm{p}<0.05\right)$ sub-dimensions, there was no significant difference between the "social" $\left(\mathrm{F}_{(2-191)}=2.773, \mathrm{p}>0.05\right)$ and "physiological" $\left(\mathrm{F}_{(2-191)}=\right.$ $1.577, \mathrm{p}>0.05)$ sub-dimensions.

According to the analysis results, while a significant difference was found between Social Media Addiction $\left(\mathrm{F}_{(2-191)}=4.386, \mathrm{p}<0.05\right)$, "Functional deterioration" $\left(\mathrm{F}_{(2-191)}=6.767, \mathrm{p}<\right.$ $0.05)$, and "control difficulties and deprivation" $\left(\mathrm{F}_{(2-191)}=4.768, \mathrm{p}<0.05\right)$ sub-dimensions by age groups of individuals $(2-191)=4.768, \mathrm{p}<0.05)$, There was no statistically significant difference between the "social isolation" $\left(\mathrm{F}_{(2-191)}=1.432, \mathrm{p}>0.05\right)$ sub-dimension. 
Table 4. The relationship between leisure satisfaction and social media addiction

\begin{tabular}{|l|l|l|l|l|l|}
\hline & & $\begin{array}{l}\text { Social Media } \\
\text { Addiction }\end{array}$ & $\begin{array}{l}\text { Functional } \\
\text { deterioration }\end{array}$ & $\begin{array}{l}\text { Control difficulty } \\
\text { and deprivation }\end{array}$ & Social isolation \\
\hline \multirow{3}{*}{ Leisure Satisfaction } & $\mathrm{r}$ & -.309 & -.325 & -.220 & -115 \\
\cline { 2 - 6 } & $\mathrm{p}$ & $\mathbf{. 0 0 0}$ & $\mathbf{. 0 1 0}$ & $\mathbf{. 0 0 6}$ & $\mathbf{. 0 0 4}$ \\
\hline \multirow{3}{*}{ Psychological } & $\mathrm{r}$ & -.341 & -.222 & -.308 & -.208 \\
\cline { 2 - 7 } & $\mathrm{p}$ & $\mathbf{. 0 0 0}$ & $\mathbf{. 0 0 0}$ & $\mathbf{. 0 3 1}$ & $\mathbf{. 0 0 0}$ \\
\hline \multirow{3}{*}{ Educational } & $\mathrm{r}$ & -.341 & -.347 & -.218 & -.361 \\
\cline { 2 - 7 } & $\mathrm{p}$ & $\mathbf{. 0 0 5}$ & $\mathbf{. 0 2 1}$ & $\mathbf{. 0 2 2}$ & $\mathbf{. 0 0 4}$ \\
\hline \multirow{3}{*}{ Recial } & $\mathrm{r}$ & -.287 & -.263 & -.157 &.-206 \\
\cline { 2 - 7 } & $\mathrm{p}$ & $\mathbf{. 0 0 0}$ & $\mathbf{. 0 0 0}$ & $\mathbf{. 0 0 0}$ & $\mathbf{. 0 0 0}$ \\
\hline \multirow{3}{*}{ Physiological } & $\mathrm{r}$ & -.306 & -.207 & -.254 & -.369 \\
\cline { 2 - 7 } & $\mathrm{p}$ & $\mathbf{. 0 0 0}$ & $\mathbf{. 0 0 4}$ & $\mathbf{. 0 0 0}$ & $\mathbf{. 0 0 6}$ \\
\hline \multirow{2}{*}{ Aesthetic } & $\mathrm{r}$ & -.259 & -.345 & -.286 & -.342 \\
\cline { 2 - 6 } & $\mathrm{p}$ & $\mathbf{. 0 2 3}$ & $\mathbf{. 0 0 0}$ & $\mathbf{. 0 0 0}$ & $\mathbf{. 0 0 0}$ \\
\hline & $\mathrm{r}$ & -.304 & -.258 & -.256 & -.308 \\
\hline & $\mathrm{p}$ & $\mathbf{. 0 2 0}$ & $\mathbf{. 0 1 5}$ & $\mathbf{. 0 0 1}$ & $\mathbf{. 0 0 0}$ \\
\hline
\end{tabular}

Table 4 showed the correlation results between LSS sub-dimensions and SMAS sub-dimensions. According to the analysis results, statistically significant negative correlations were found between LSS and SMAS sub-dimensions $(\mathrm{p}<0.05)$.

According to the analysis results, a moderate negative correlation was found between "leisure satisfaction" and "social media addiction" $(r=-.309)$.

\section{Discussion and Conclusion}

In recent years, the advancement of technology, the invention of the latest technology smartphones, computers and tablets, and the increase in social media platforms increased the dependence of people on these platforms to keep up with today's conditions. In parallel with this addiction, it isolated people from society and caused health problems by pushing people to immobilize. Advancing technology was also known to increase people's leisure. The question of whether the satisfaction achieved in these leisure activities affected social media addiction was the aim of this study.

In the study, it was thought that it was very important for young people to be a research group, especially because they were more dependent on social media. A significant difference was 
found between the "social" and "aesthetic" sub-dimensions of LSS according to the gender of the participants. As a result, it can be said that the significant difference in these sub-dimensions is in favour of female, and it can be said that female provide more satisfaction in leisure time than male. While there were studies supporting this result in the literature (Sönmezoğlu et al., 2014; Yazgeç, 2019; Serdar, 2016; Tepeköylü Öztürk, 2019; Beşikçi, 2016; Çakır, 2017; Ngai, 2005), there were studies that did not support the results of our study as well (Ardahan \& Yerlisu Lapa, 2010; Broughton \& Beggs, 2007; Çelik, 2011).

Although the mean scores of the participants were in favour of female among the SMAS sub-dimensions according to their gender, no statistically significant difference was found. It was observed that there were studies that support our literature research (Aktan, 2018; Baz, 2018) and also there were studies that did not support (Y1lmazsoy \& Kahraman, 2017; Deniz \& Gürültü, 2018; Tutgun Ünal, 2015; Çiftçi, 2018). Whether social media addiction differed significantly between genders was an expected situation. Especially the differences in the sample group and the differences in the time periods of the research can be expected to reveal meaningful or non-significant results between the genders.

According to the results, significant difference was found between the "psychological", "educational", "relaxation" and "aesthetics" sub-dimensions of LSS according to the age groups of the individuals. It was seen that the significant difference was between the individuals in the 18-21 age group and the individuals in the 22-25 age group, and this significant difference was found to be in favour of the individuals in the 18-21 age group. In this context, it can be concluded that individuals in the 18-21 age group had higher leisure satisfaction. When the literature was examined, a significant difference was found between leisure satisfaction according to age groups in the studies conducted by Ayhan et al. (2018), Ayyıldız (2015) and Ayyıldız and Gökyürek (2016), while in the study conducted by Siyahtaş (2020), there was a significant negative relationship in the "educational" sub-dimension. This result was parallel to our study.

According to the research results, a statistically significant difference was found between the sub-dimensions of SMAS according to the age groups of the individuals. While it was determined that the significant difference determined was between the age groups 18-21 and $22-25$, it can be said that especially individuals in the 18-21 age group had higher social media addiction. When the studies conducted were examined, in the studies conducted by Çiftçi (2018), Yayman (2019), and Bilginer (2020), no significant differences were found between social media addictions according to the ages of the participants. Therefore, the studies conducted and the result of our research were not parallel.

Considering that especially the young generation's usage of social media was higher, the effect of leisure satisfaction on social media addiction was the main hypothesis of the study. As a result, a moderate negative relationship was found between the satisfaction achieved by individuals participating in leisure activities and social media addiction. In previous studies, it was concluded that satisfaction achieved in leisure increased life satisfaction (Köksal, 2019), perceived freedom (Serdar, 2016), life well-being (Liu, 2014) and motivation (Beşikçi et al., 2019). Moreover, studies concluded that satisfaction achieved in leisure time reduced 
depression (Chang et al., 2018) and loneliness (Siyahtaş, 2020). Therefore, in our study, the expected result was that leisure time satisfaction reduced social media addiction, and it was thought that all individuals, especially young individuals, should give more importance to leisure and provide a higher level of satisfaction in these time periods.

\section{References}

Akgül, B. M., Ayyıldız, T., \& Karaman, M. (2014). Spor merkezlerinde rekreatif faaliyetlere katılan bireylerin serbest zaman tatmin düzeylerinin farklı değişkenlere göre incelenmesi. Niğde Üniversitesi Beden Ĕ̈itimi ve Spor Bilimleri Dergisi, 8(3), 278-287.

Aktan, E. (2018). Üniversite Öğrencilerinin Sosyal Medya Bağımlılık Düzeylerinin Çeşitli Değişkenlere Göre İncelenmesi. Erciyes İletişim Dergisi, 5(4), 405-421. https://doi.org/ 10.17680/erciyesiletisim.379886

Alkaya, Ö. (2020). Ergenlerde sosyal medya bă̆ımlılı̆̆ı, umut ve denetim odağı arasındaki ilişkinin incelenmesi (Yüksek Lisans Tezi, Bahçeşehir Üniversitesi Eğitim Bilimleri Enstitüsü Rehberlik Ve Psikolojik Danışmanlık Yüksek Lisans Programı, İstanbul.

Ardahan, F., \& Yerlisu Lapa, T. (2010). Üniversite öğrencilerinin serbest tatmin düzeylerinin cinsiyete ve gelire göre incelenmesi. Hacettepe Spor Bilimleri Dergisi, 21(4), 129-136.

Ayyıldız, T. (2015). Rekreatif dans faaliyetlerine katılan bireylerin serbest zaman serbest zaman tatmin düzeylerinin incelenmesi (Yüksek Lisans Tezi, Gazi Üniversitesi Sağlık Bilimleri Enstitüsü Sporda Psiko-Sosyal Alanlar Programı, Ankara).

Ayyıldız, T., \& Gokyürek, B. (2016). Examination of leisure satisfaction levels of individuals participating in recreative dance activities. Science, Movement and Health, 16(2), 147-155.

Balta, E. (2019). Sosyal Medya Bă̆ımlılı̆̆ının Orta Öğretim İkinci Kademe Öğrencileri Arasındaki Nedenleri, Eğitsel Bilişsel Sonuçları (Sivas Merkez İlçe Örneği) (Yükssek Lisans Tezi, Cumhuriyet Üniversitesi, Sosyal Bilimler Enstitüsü, Sivas).

Bayraktar, M. (2020). Üniversite öğrencilerinde bağlanma stilleri, sosyal medya bă̆ımlılı̆̆ ve koşullu öz-değer arasındaki ilişki (Yüksek Lisans Tezi, Ondokuz Mayıs Üniversitesi Lisansüstü Eğitim Enstitüsü Eğitim Bilimleri Ana Bilim Dalı, Samsun).

Baz, F. Ç. (2018). Sosyal Medya Bağımlılı̆̆ı: Üniversite Öğrencileri Üzerine Çalışma. Uluslararası Toplum Araştırmaları Dergisi, 9(16), 276-295. https://doi.org/10.26466/opus. 470118

Beard, J. G., \& Ragheb, M. G. (1980). Measuring Leisure Satisfaction. Journal of Leisure Research, 12, 20-33. https://doi.org/10.1080/00222216.1980.11969416

Becan, C. (2018). Sosyal Medya Bağımlılı̆̆ının Haber Takibi Motivasyonları Üzerine Etkisi. Erciyes Iletişim Akademia Dergisi, 5(3), 238-256. https://doi.org/10.17680/erciyesakademia. 350085 
Beggs, B., Kleparski, T., Elkins, D., \& Hurd, A. (2014). Leisure Motivation of Older Adults in Relation to Other Adult Life Stages. Activities, Adaptation \& Aging, 38, 175-187. https://doi.org/ 10.1080/01924788.2014.935910

Beşikçi, T. (2016). Macera rekreasyonunda heyecan arayışl, serbest zaman motivasyonu ve serbest zaman tatmini arasındaki ilişkinin incelenmesi: Çok hafif hava araçları (ÇHHA) pilot örneği (Yüksek Lisans Tezi, Manisa Celal Bayar Üniversitesi Sosyal Bilimler Enstitüsü Rekreasyon Anabilim Dalı Rekreasyon Programı, Manisa).

Beşikçi, T., Irkın, F., \& Güzel, P. (2019). Serbest zaman motivasyonu ve serbest zaman doyumu ilişkisi mücadele sporlar ile ilgilenen bireyler üzerine bir araştırma. 2 Dünya Spor Bilimleri Araştırmaları Kongresi, Tam Metin Bildiri Kitabı.

Bilginer, A. (2020). Lise öğrencilerinde sosyal medya bă̆lmlılı̆̆ ile öz yeterlik düzeyi arasındaki ilişkinin incelenmesi: mardin ili örneği (Yüksek Lisans Tezi, Çă̆ Üniversitesi Sosyal Bilimler Enstitüsü Psikoloji Anabilim Dalı, Mersin).

Broughton, K., \& Beggs, B. A. (2006). Leisure satisfaction of older adults. Activities, Adaptation \& Aging, 31(1), 1-18. https://doi.org/10.1300/J016v31n01_01

Çakır, V. O. (2017). Üniversite öğrencilerin serbest zaman doyum düzeyleri ile serbest zaman yönetimleri arasındaki ilişki. Gaziantep Üniversitesi Spor Bilimleri Dergisi, 2(3), 17-27.

Çelik, G. (2011). Kamu kurumlarında çalışan engelli bireylerin serbest zaman engellerinin ve tatmin düzeylerinin incelenmesi (Antalya Merkez Örneği) (Yüksek Lisans Tezi, Akdeniz Üniversitesi Sosyal Bilimler Enstitüsü Spor Yöneticiliği Anabilim Dalı, Antalya).

Chang, P., Lin, Y., \& Song, R. (2018) Leisure satisfaction mediates the relationships between leisure settings, subjective well-being, and depression among middle-aged adults in urban china. Springer Nature and the International Society for Quality Of-Life Studies, 14(1), 1001-1017. https://doi.org/10.1007/s11482-018-9630-3

Chen, Y. C., Li, R. H., \& Chen, S. H. (2013). Relationships Among Adolescents' Leisure Motivation, Leisure Involvement, and Leisure Satisfaction: A Structural Equation Model. Social Indicatiors Research, 110(3), 1187-1199. https://doi.org/10.1007/s11205-011-9979-2

Choi, S. H., \& Fu, X. (2015). Re-Examining the Dimensionality of Leisure Motivation and Leisure Satisfaction in a Multicultural Context: Evidence from Macau. Humanities \& Social Sciences Reviews, 3(1), 6-10.

Çiftçi, H. (2018). Üniversite öğrencilerinde sosyal medya bağımlılı̆̆ı. Manas Sosyal Araştırmalar Dergisi, 7(4), 417-434.

Çolak, Ç. H. (2020). Lise ögrencilerinde sosyal medya bağmlılı̆̆ ve duygu düzenleme becerılerinin kişılık özelliklerine ve çeşitli değşskenlere göre incelenmesi (Yüksek Lisans Tezi, Sakarya Universitesi Eğitim Bilimleri Enstitüsü Eğitim Bilimleri Anabilim Dalı Eğitimde Psikolojik Hizmetler Bilim Dalı, Sakarya).

Demiral, S. (2018). Açık alan rekreasyonuna katılan bireylerin serbest zaman tatmin 
düzeylerinin incelenmesi: Şavşat-Karagöl Örneği (Yüksek Lisans Tezi, Batman Üniversitesi Sosyal Bilimler Enstitüsü Rekreasyon Yönetimi Anabilim Dalı, Batman).

Deniz, L., \& Gürültü, E. (2018). Lise Öğrencilerinin Sosyal Medya Bağımlılıkları. Kastamonu Education Journal, 26(2), 355-367. https://doi.org/10.24106/kefdergi.389780

Echeburua, E., \& Corral, P. (2010). Addiction to New Technologies And To Online Social Networking İn Young People: A Newchallenge. Adicciones, 22, 91-95. https://doi.org/ 10.20882/adicciones. 196

Edginton, R. C. (2006). World Leisure: Enhancing Quality of Life. International Journal of Applied Sports Sciences, 18(2), 108-120.

Ekinci, Ü. (2019). Bedensel engelli bireylerin katıldıklart serbest zaman etkinliklerinden tatmin olma ve algllanan özgürlük düzeylerinin incelenmesi (Yüksek Lisans Tezi, Akdeniz Üniversitesi Sosyal Bilimler Enstitüsü Rekreasyon Ana Bilim Dalı, Antalya).

Gökçe, H. (2008). Serbest zaman doyumunun yaşam doyumu ve sosyo-demografik değişkenlerle ilişkisinin incelenmesi (Yüksek Lisans Tezi, Pamukkale Üniversitesi Sağlık Bilimleri Enstitüsü Sporda Psiko-Sosyal Alanlar Anabilim Dalı, Denizli).

Gökçe, H., \& Orhan, K. (2011). Serbest zaman doyum ölçeğinin Türkçe geçerlik ve güvenirlik çalışması. Spor Bilimleri Dergisi, 22(4), 139-145.

Güngörmüş, H. A., Serdar, E., Beşikçi, T., \& Dirilik, Y. (2018). Fitness Merkezlerinden Hizmet Alan Bireylerin Serbest Zaman Doyumu ve Psikolojik İi Oluş İişkisi (pp. 423-424). Uluslararası Rekreasyon ve Spor Yönetimi Kongresi, Bildiri Özetleri Kitabı.

Gürbüz, B., \& Henderson, K. (2013). Exploring the Meanings of Leisure among Turkish University Students. Croatian Journal of Education, 15(4), 927-957. Retrieved from https://hrcak.srce.hr/113287

Henderson, K. (2010). Leisure Studies in the 21St Century: The Sky is Falling? Leisure Sciences: An Interdisciplinary Journal, 32(4), 391-400. https://doi.org/10.1080/01490400. 2010.488614

Hideo, M., Shintaro, S., Akira, A., \& Koichi, C. (2018). Exploring the relationship among leisure engagement, affective and cognitive leisure involvement, and subjective happiness: a mediating role of leisure satisfaction. World Leisure Journal, 60(2), 111-126. https://doi.org/ $10.1080 / 16078055.2018 .1444669$

Hou, Y. (2003). Taiwanese college students and lesiure: The relationship between their leisure motivations and leisure constraints (PhD Dissertation, Spalding University).

Huang, C. (2003). The relationships among leisure participation, leisure satisfaction, and life satisfaction of college students in Taiwan (PhD Dissertations \& Theses, University of Incarnete Word).

Ito, E., Walker, G. J., Liu, H., \& Mitas, O. (2017). A Cross-Cultural/National Study of Canadian, Chinese, and Japanese University Students' Leisure Satisfaction and Subjective 
Well-Being. Leisure Sclences, 39(2), 186-204. https://doi.org/10.1080/01490400.2016. 1165637

Jensen, C., \& Naylor, J. (2005). Opportunities in Recreation and Leisure Careers. Illinois: Vgm Career Horizon.

Kaas, E. T., \& Artımaç, A. (2017). Free time management, leisure participation and satisfaction in university students. Journal of Educational and Instructional Studies in the World, 7(4), 2146-7463.

Karasar, N. (2020). Bilimsel Araştırma Yöntemi. Kavramlar İlkeler Teknikler (35 Basım). Nobel Akademik Yayıncılık, Ankara.

Köksal, G. (2019). Serbest zaman doyumu ve yaşam tatmini ilişkisi: beden eğitimi ögretmenleri örneği (Yüksek Lisans Tezi, Selçuk Üniversitesi Sağlık Bilimleri Enstitüsü Spor Yöneticiliği Anabilim Dalı, Konya).

Kuss, D. J., \& Griffiths, M. D. (2011). Online Social Networking and Addiction: A Literature Review of Empirical Research. International Journal of Environmental and Public Health, 3528-3552. https://doi.org/10.3390/ijerph8093528

Li, J., Hsu, C. C., \& Lin, C. T. (2019). Leisure Participation Behavior and Psychological Well-Being of Elderly Adults: An Empirical Study of Tai Chi Chuan in China. International Journal of Environmental Research and Public Health, 16(3387), 1-19. https://doi.org/ 10.3390/ijerph16183387

Liu, H. (2014). Personality, leisure satisfaction, and subjective well-being of serious leisure participants. Social Behavior and Personality, 42(7), 1117-1126. https://doi.org/10.2224/sbp. 2014.42.7.1117

Longstreet, P., \& Brooks, S. (2017). Life Satisfaction: A Key to Managing Internet and Social Media Addiction. Technology in Society, 50, 73-77. https://doi.org/10.1016/j.techsoc.2017. 05.003

Muzınduts1, P. F., \& Masango, Z. (2015). Determinants of leisure satisfaction among undergraduate students at a south african university. International Journal of Business and Management Studies, 7(2), 1-15.

Ngai, V. T. (2005). Leisure satisfaction and quality of life in Macao, China. Leisure Studies, 24(2), 195-207. https://doi.org/10.1080/02614360412331313502

Özçağlayan, M. (1998). Yeni iletişim teknolojileri ve değişim. İstanbul: Alfa Yayınları.

Paggi, M. E., Jopp, D., \& Hertzog, C. (2016). The Importance of Leisure Activities in the Relationship between Physical Healt and Well-Being in a Life Span Sample. Gerontology, 62, 450-458. https://doi.org/10.1159/000444415

Park, K. W., Lee, C. W., \& Min, J. K. (2016). Effect of serious leisure experience on the leisure satisfaction among senior sport games participants. Journal of Physical Education and Sport, 92, 584-591. 
Park, S., Chiu, W., \& Won, D. (2017). Effects of physical education, extracurricular sports activities, and leisure satisfaction on adolescent aggressive behavior: A latent growth modeling approach. PLoS ONE, 12(4), 1-13. https://doi.org/10.1371/journal.pone.0174674

Serdar, E. (2016). Üniversite öğrencilerinin katıldıkları serbest zaman etkinliklerinden tatmin olma ve algllanan özgürlük düzeylerinin incelenmesi (Yüksek Lisans Tezi, Marmara Üniversitesi Sağlık Bilimleri Enstitüsü Beden Eğitimi Ve Spor Anabilim Dalı, İstanbul).

Serdar, E., \& Mungan Ay, S. (2016). Üniversite öğrencilerinin serbest zaman etkinliklerine katılım biçimlerine göre tatmin olma ve algılanan özgürlük düzeylerinin incelenmesi. Sosyal Bilimler Dergisi, 3(9), 365-374. https://doi.org/10.16990/SOBIDER.3332

Serdar, E., Demirel, M., Harmandar Demirel, D., \& Donuk, B. (2018). Üniversite öğrencilerinin serbest zaman doyum düzeyleri ile mutluluk düzeyleri arasındaki ilişki. Sosyal Bilimler Dergisi, 5(28), 429-438. https://doi.org/10.16990/SOBIDER.4412

Siyahtaş, A. (2020). Serbest zaman etkinliklerine katılan bireylerin yalnızlık düzeyleri ile doyum düzeylerinin incelenmesi (Yüksek Lisans Tezi, İstanbul Üniversitesi-Cerrahpaşa Lisansüstü Eğitim Enstitüsü Spor Yönetim Bilimleri Anabilim Dalı Spor Yönetim Bilimleri Tezli Yüksek Lisans Programı, İstanbul).

Sönmezoğlu, U., Polat, E., \& Aycan, A. (2014). Gençlik merkezi üyeleri ve bazı değişkenlere göre serbest zaman tatmin düzeyleri. International Journal of Science Culture and Sport, 1, 219-229. https://doi.org/10.14486/IJSCS91

Tepeköylü Öztürk, Ö. (2019). Leisure Satisfaction of Sports Science Students. International Education Studies, 12(4), 42-48. https://doi.org/10.5539/ies.v12n4p42

Turban, E., King, D., Lee, J., \& Viehland, D. (2002). Electronic commerce: A managerial perspective 2002. Prentice Hall, Division of Simon and Schuster One Lake Street Upper Saddle River, NJ, USA.

Tutgun Ünal, A. (2015). Sosyal medya bă̆ımlılı̆̆l: üniversite öğrencileri üzerine bir araştırma (Doktora Tezi, Marmara Üniversitesi Sosyal Bilimler Enstitüsü Gazetecilik Ana Bilim Dalı Bilişim Bilim Dalı, İstanbul).

Ulusoy, K. (2017). Tarih öğretmenlerinin madde bağımlılığ1 ve medya bağımlılığı ile ilgili düşünceleri. Kastamonu Eğitim Dergisi, 25(1), 385-400.

Wilson, K., Fornasier, S., \& White, K. M. (2010). Psychological predictors of young adults' use of social networking sites. Cyberpsychology, Behavior and Social Networking, 13, 173-177. https://doi.org/10.1089/cyber.2009.0094

Yang, Y. S. (2006). A Study on the Relationship among Participation of Leisure Activities, Leisure Constraints and Well-Being of the Students in National Changhua Senior School of Commerce. Ta-Yeh University, Taiwan.

Yaşartürk, F. (2019). Analysis of the Relationship between the Academic Self-Efficacy and Leisure Satisfaction Levels of University Students. Journal of Education and Training 
Studies, 7(3), 106-115. https://doi.org/10.11114/jets.v7i3.3988

Yayman, E. (2019). Ergenlerde sosyal medya bă̆ımlılı̆̆ı oyun bağımlılı̆̆ ve aile işlevleri arasındaki ilişkinin incelenmesi (Yüksek Lisans Tezi, İstanbul Sabahattin Zaim Üniversitesi Sosyal Bilimler Enstitüsü Eğitim Bilimleri Anabilim Dalı Rehberlik Ve Psikolojik Danışmanlık Bilim Dalı, İstanbul).

Yazgeç, G. (2019). Doğa ve macera rekreasyonu etkinliklerine katılan bireylerin serbest zaman doyumu ve mutluluk düzeylerinin incelenmesi: Fethiye destinasyonu örneği (Yüksek Lisans Tez, Manisa Celal Bayar Üniversitesi Sosyal Bilimler Enstitüsü Rekreasyon Anabilim Dal1 Rekreasyon Programı, Manisa).

Yılmazsoy, B., \& Kahraman, M. (2017). Üniversite Öğrencilerinin Sosyal Medya Bağımlılığı ile Sosyal Medyayı Eğitsel Amaçlı Kullanımları Arasındaki İlişkinin İncelenmesi: Facebook Örneği. Journal of Instructional Technologies \& Teacher Education, 6(1), 9-20.

\section{Copyright Disclaimer}

Copyright for this article is retained by the author(s), with first publication rights granted to the journal.

This is an open-access article distributed under the terms and conditions of the Creative Commons Attribution license (http://creativecommons.org/licenses/by/3.0/). 